\title{
MIR194-1 pre-miRNA
}

National Cancer Institute

\section{Source}

National Cancer Institute. MIR194-1 pre-miRNA. NCI Thesaurus. Code C95039.

MIR194-1 pre-miRNA (85 bases) is encoded by the human MIR194-1 gene. This ribonucleotide may be involved in the regulation of gene transcription. 